\title{
Three vole species and one (?) novel arvicolid hantavirus pathogen: Tula virus revisited
}

J Clement ${ }^{1}$, M Van Ranst ${ }^{1}$

1. National Hantavirus Reference Centre, Laboratory of Clinical and Epidemiological Virology and Rega Institute for Medical Research, University of Leuven, U.Z. Gasthuisberg, Belgium

Correspondence: Jan Clement (jan.clement@uzleuven.be)

Citation style for this article:

Clement J, Van Ranst M. Three vole species and one (?) novel arvicolid hantavirus pathogen: Tula virus revisited. Euro Surveill. 2016;21(2):pii=30108. DOI: http:// dx.doi.org/10.2807/1560-7917.ES.2016.21.2.30108

Article submitted 03 January 2016 / accepted on 14 January 2016 / published on 14 January 2016

To the editor: The recent confirmation by RT-PCR of a case of haemorrhagic fever with renal syndrome (HFRS), induced by Tula virus (TULV) in France [1], confirms the pathogenicity of this arvicolid hantavirus, a fact not generally acknowledged yet, or at least still contested [2]. The clinical presentation of the demonstrated TULV HFRS case was, however, unusual: besides the classic fever with thrombocytopenia and elevated transaminases, leukopenia instead of leukocytosis with left shift was found, and the renal function remained strictly within normal limits. However, renal involvement was nevertheless indicated by transient microscopic haematuria. Regrettably, transient but massive and unselective proteinuria, the renal hallmark in probably all hantavirus infections, was once more not discussed. Interestingly, a false-positive serological screening result for another arvicolid hantavirus, Puumala virus (PUUV), was obtained in three assays of two different formats (immunofluorescence assay (IFA) and ELISA), but could not be confirmed by routine RT-PCR, i.e. by using PUUV-specific primers [1]. As subsequently shown by Reynes et al., TULV and PUUV are two closely related, yet genetically distinct hantavirus species, both carried by distinct voles of the Arvicolinae, a subfamily of the Cricetidae rodent family [1].

Consequently, it is important to remember that the classic TULV rodent reservoir, the common vole (Microtus arvalis), is present throughout most of western Europe, except Fennoscandia and the British Isles, with however a presence on the Orkney Islands. The common vole is also present in northern and even central Spain. This means in serological practice that an HFRSlike infection in Fennoscandia and/or the British Isles, documented by standard IFA and/or ELISA to be IgMpositive for PUUV, could thus (until recently) readily be accepted as a true PUUV infection, given the complete absence of common voles in the area. However, the same conclusion is not so evident for a PUUV-positive
HFRS case in the rest of north-western Europe, where even strong positive serological results for PUUV could in fact point to a TULV infection spread by common voles, as exemplified by this French case. This is valid also for northern and central Spain, northern Italy and the Balkan Peninsula.

Things become even more complex when the geographical spread of the field vole (Microtus agrestis) is also considered. Indeed, its habitat, much more extensive than that of its cousin $M$. arvalis, includes the whole of Europe except Ireland and Mediterranean countries. Several reports mention the presence of a TULV-like agent in field voles; the most recent example is Tatenale virus, the first biomolecularly proven arvicolid hantavirus in the United Kingdom, characterised in a field vole in north-western England. Like TULV, it provoked false-positive PUUV reactions in serology [3]. Finally, a TULV-like agent has also been documented in the Eurasian water vole (Arvicola amphibius, formerly Arvicola terrestris), which has the same extensive European spread as the field vole; infection with this virus therefore has the same potential of yielding PUUV-like serological cross-reactions [4]. Moreover, this novel TULV-like agent has already been found to infect asymptomatic forest workers, even in nonendemic areas of eastern Germany [5].

In summary, in western Europe, including Fennoscandia and mainland England, an ELISA-and/or IFA-positive result for PUUV does not automatically mean a true PUUV infection, as now convincingly shown [1]. Few isolated European HFRS case reports, and virtually no national European or Russian PUUV seroprevalence studies have so far excluded this possibility. Northern Ireland, where none of the above vole species are present, remains a noticeable arvicolid-free exception [6]. Admittedly, all this bears little practical clinical significance for physicians treating a suspected PUUV case, since TULV infections seem even milder than their 
PUUV counterpart. In fact, it is even likely that a prior PUUV infection, subclinical or not, might confer at least partial, but probably life-long cross-immunoprotection against its cousin-pathogen TULV.

\section{References}

1. Reynes JM, Carli D, Boukezia N, Debruyne M, Herti S. Tula hantavirus infection in a hospitalised patient, France, June 2015. Euro Surveill. 2015;20(50):30095. DOI: 10.2807/15607917.ES.2015.20.50.30095 PMID: 26691901

2. Clement J, Frans J, Van Ranst M. Human Tula virus infection or rat-bite fever?Eur J Clin Microbiol Infect Dis. 2003;22(5):332-3, author reply 334-5. DOI: $10.1128 / J C M .41 .10 .4894-4897.2003$ PMID: 12736795

3. Pounder KC, Begon M, Sironen T, Henttonen H, Watts PC, Voutilainen L, et al. Novel hantavirus in field vole, United Kingdom. Emerg Infect Dis. 2013;19(4):673-5. DOI: 10.3201/ eid1904.121057 PMID: 23750506

4. Schlegel M, Kindler E, Essbauer SS, Wolf R, Thiel J, Groschup $\mathrm{MH}$, et al. Tula virus infections in the Eurasian water vole in Central Europe. Vector Borne Zoonotic Dis. 2012;12(6):503-13. DOI: $10.1089 / v b z .2011 .0784$ PMID: 22225425

5. Mertens M, Hofmann J, Petraityte-Burneikiene R, Ziller M, Sasnauskas K, Friedrich R, et al. Seroprevalence study in forestry workers of a non-endemic region in eastern Germany reveals infections by Tula and Dobrava-Belgrade hantaviruses. Med Microbiol Immunol (Berl). 2011;200(4):263-8. DOI: 10.1007/S00430-011-0203-4 PMID: 21611907

6. McKenna P, Clement J, Matthys P, Coyle PV, McCaughey C. Serological evidence of Hantavirus disease in Northern Ireland.J Med Virol. 1994;43(1):33-8. DOI: 10.1002/ jmv.1890430107 PMID: 7916033

\section{License and copyright}

This is an open-access article distributed under the terms of the Creative Commons Attribution (CC BY 4.0) Licence. You may share and adapt the material, but must give appropriate credit to the source, provide a link to the licence, and indicate if changes were made.

This article is copyright of the authors, 2016. 